\title{
Editorial
}

\section{A year of transformation comes to its end}

\author{
Hans-Joachim Freisleben \\ ${ }^{1}$ Past \& Honorary President, German-Indonesian Medical Association (DIGM e.V.), Germany \\ ${ }^{2}$ Editorial Board Member Medical Journal of Indonesia, Jakarta, Indonesia
}

Again, a busy year comes close to its end. Our editor-in-chief, Dr. Nafrialdi had announced a "year of transformation" for the Medical Journal of Indonesia. ${ }^{1}$ Several changes have been made - we do hope they can be considered as improvements certainly not all goals we were aiming to have been achieved, yet. However, speaking a bit "pro domo" I think we can be proud of what Med J Indones (MJI) has achieved so far: it has become one of the best Medical Journals in Indonesia. This does not depend on accreditation or referencing in search engines, it depends on its scientific content. I dare to say so, because for many years, I have been a referee in the peer review process of various scientific journals and a member of evaluation boards for awarding the best publications nationally and internationally. On the average, I can say that the quality of articles published in MJI was better than that of many other journals (not only Indonesian ones), because we widely managed to present a message in each of our publications. When I read manuscripts and even published articles in certain journals, I am asking myself "What do the authors try to tell the reader?" I think our editorial team takes well care that each of the articles published by MJI contains "a message" to the readers. If we continue to follow this goal, MJI will certainly soon reach sufficient international acknowledgment, no matter how it is accredited, domestically. To this end, a very important step has already been reached this year: all four issues contain articles not only by Indonesian authors, but also from abroad.

This issue presents a several interesting contributions and I want to focus on two groups, a group of three articles dealing with cancers and another group of papers connected with oxidative stress and/or antioxidants: antioxidant properties of flavonoids, ${ }^{2}$ the antioxidant effects of Hibiscus sabdariffa Linn. in excessive physical training, ${ }^{3}$ and the positive effect of high dose antioxidants on lymphocyte chromosome breakage in low benzene exposure. ${ }^{4}$ Oxidative stress and antioxidants have become biomedical "evergreens" and flavonoids are a class of very potent polyphenolic antioxidants. However, we must be careful to generalize, because the potency of antioxidants depends very much on experimental settings. A simple example may demonstrate my point: if we have an aqueous test system, vitamin $\mathrm{C}$ will have high antioxidant potency; that of vitamin $\mathrm{E}$ will be lower, and in a more lipophilic, yet intermediate test medium, it may be the other way around, and in a highly hydrophobic test medium, carotenoids will have much higher antioxidant potency than both of them. However, in vivo and even more under clinical condition this may look very different. This is one of the reasons why so many results from biomedical experiments with antioxidants cannot be verified under clinical conditions. We must exactly define the "in-vivo" condition, like "excessive physical training" or the "lymphocyte chromosome breakage in low benzene exposure" and then define which antioxidant at which dose exerts best preventive or therapeutic results. It is a pity that domestic regulations widely prevent citation of literature older than ten years. Basic yet very detailed studies had been published on flavonoids in the nineties, well compiled in. ${ }^{5}$ They disserve being mentioned in this context.

The other group of articles deals with cancers, e.g., the very interesting report of a rare case of primary rectal melanoma by a team of authors from India. ${ }^{6}$ Not less interesting is an in vitro study on the cytotoxic effect of $\gamma$-sitosterol isolated from the medicinal plant "Kejibeling" (Strobilanthes crispus) on several cancer cell lines, which revealed that the effect was mediated by the down-regulation of c-myc

Copyright@2014 Authors. This is an open access article distributed under the terms of the Creative Commons Attribution-NonCommercial-ShareAlike 4.0 International License (http://creativecommons.org/licenses/by-nc-sa/4.0/), which permits unrestricted non-commercial use, distribution, and reproduction in any medium, provided the original author and source are properly cited. 
expression and induction of apoptotic pathways. ${ }^{7}$ A third article on cancer research deals with the identification of a pathogenic pathway in basal-like breast cancer. $^{8}$

The other two articles in this issue are not less interesting, because they deal with widespread health problems in Indonesia, thalassemia and preeclampsia. ${ }^{9,10}$ Since it is well known that thalassemia patients suffer from instability of their erythrocytes in blood circulation, it is very important to know, how far thalassemia trait of donors influences the stability of their stored blood. ${ }^{9}$ Last but not least, we have a case of chronic thromboembolic pulmonary hypertension in a woman with history of Caesarian Section due to preeclampsia. ${ }^{10}$

We hope that the collection of articles in this issue is a valuable finale of MJI. Volume 23, 2014 and we want to wish both our esteemed readers and our journal a successful and prosperous New Year, 2015.

\section{REFERENCES}

1. Nafrialdi. Editorial: Year of transformation. Med J Indones. 2014;23(1):1-2.
2. Banjarnahor SDS, Artanti N. Antioxidant properties of flavonoids. Med J Indones. 2014;23(4):239-44.

3. Ilyas EII, Kartinah NT, Andraini T, Goenarjo RA, Kahandjak DN. The effects of Hibiscus sabdariffa Linn. on insulin-like growth factor binding protein 3 (IGFBP-3) to prevent overtraining. Med J Indones. 2014;23(4):187-91.

4. Soemarko DS, Mansyur M. Lymphocyte chromosome breakage in low benzene exposure among Indonesian workers. Med J Indones. 2014;23(4):223-8.

5. Rice-Evans CA, Packer L, editors. Flavonoids in Health and Disease. New York: Marcel Dekker, Inc; 2003.

6. Das S, Mandal TS, Paul S, Datta P, Sinhababu AK. Primary rectal melanoma - a case report. Med J Indones. 2014;23(4):229-31.

7. Endrini S, Rahmat A, Ismail P, Taufiq-Yap YH. The effect of $\gamma$-sitosterol from Kejibeling (Strobilanthes crispus) and the mechanism of action towards c-myc gene expression and apoptotic pathway. Med J Indones. 2014;23(4):203-8.

8. Dwina Y, Kodariah R, Hardjolukito ESR. Identification of pathogenesis pathway in basal-like breast cancer based on mutant $\mathrm{p} 53$ protein and topoisomerase-II $\alpha$ expression. Med J Indones. 2014;23(4):197-202.

9. Maharani EA, Soedarmono YSM, Nainggolan IM. Frequency of thalassemia carrier and $\mathrm{Hb}$ variant and the quality of stored donor blood. Med J Indones. 2014;23(4):209-12.

10. Asbarinsyah NA, Soerarso RS, Hersunarti N, Siswanto BB. Chronic thromboembolic pulmonary hypertension in young women with history of caesarian section. Med J Indones. 2014;23(4):232-8.

pISSN: 0853-1773 • eISSN: 2252-8083 • http://dx.doi.org/10.13181/mji.v23i4.1175• Med J Indones. 2014;23:185-6 Correspondence author: Hans-Joachim Freisleben, hj.freisleben@t-online.de 